\title{
Left ventricular pseudoaneurysm: imaging
}

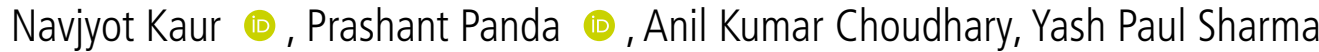

Cardiology, Postgraduate Institute of Medical Education and Research, Chandigarh, India

\section{Correspondence to}

Dr Prashant Panda: prashantpanda85@gmail.com

Accepted 1 June 2021

\section{DESCRIPTION}

Left ventricular (LV) pseudoaneurysm is a rare but potentially fatal complication of myocardial infarction (MI) which needs to be differentiated from true LV aneurysm. ${ }^{1}$ Most of the LV pseudoaneurysms post MI are located at the inferior and posterolateral wall (82\% of all post MI pseudoaneurysms). ${ }^{12}$ We hereby present an anterolateral LV pseudoaneurysm post MI, which makes it even a rarer entity.

A 78-year-old frail woman, a known case of diabetes mellitus type 2 and hypertension, presented to the emergency department with worsening dyspnoea of 2 weeks' duration. She had a history of chest discomfort 1 week prior to the onset of dyspnoea, which resolved with some medication prescribed by the local doctor. On presentation, she was orthopneic with saturation of $82 \%$ at room air and had mean arterial pressure of $76 \mathrm{~mm} \mathrm{Hg}$. She had a gallop rhythm with bilateral widespread crepitations in the chest. N-terminal pro-B-type natriuretic peptide, troponin $\mathrm{T}$ and creatine kinase $\mathrm{MB}$ were $6980 \mathrm{pg} / \mathrm{mL}$ (normal $<300 \mathrm{pg} / \mathrm{mL}$ ), 0.56 $\mathrm{ng} / \mathrm{mL}$ (normal $<0.4 \mathrm{ng} / \mathrm{mL}$ ) and $42 \mathrm{IU} / \mathrm{L}$ (normal 5-25 IU/L), respectively. Reverse transcription PCR for COVID-19 was negative. Transthoracic 2D echocardiography revealed an ejection fraction of $20 \%$ with a large anterolateral pseudoaneurysm which was confirmed on 3D echocardiography (figure 1A-D). Her electrocardiogram revealed QS in V1-V6, I and aVL (figure 2). She was managed with antiplatelets, anticoagulation, non-invasive ventilation and diuretics. After haemodynamic stabilisation, she was taken up for coronary angiography and ventriculography. Coronary angiography revealed diffuse disease of the left anterior

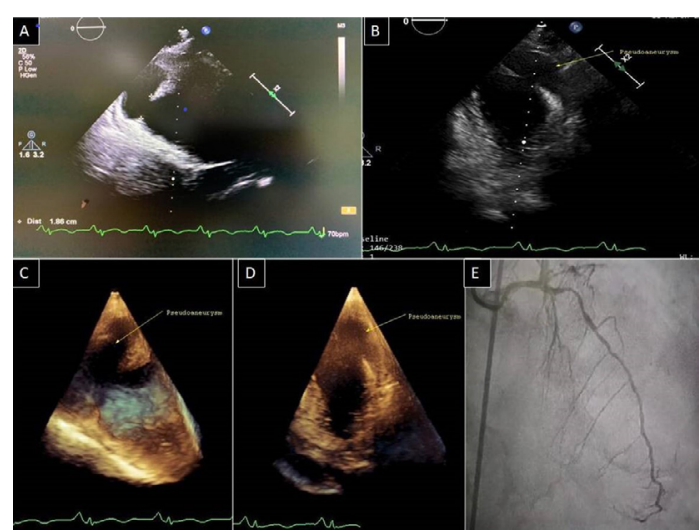

Limited 2021. No commercial re-use. See rights and permissions. Published by BMJ.

To cite: Kaur N, Panda P,
Choudhary AK, et al. BMJ
Case Rep 2021;14:e243913.
doi:10.1136/bcr-2021-
243913

Figure 1 Transthoracic echocardiography (TTE) 2D, parasternal long axis (PLAX) and apical four-chamber (A4C) views showing pseudoaneurysm (A,B). TTE 3D, PLAX and $A 4 C$ views showing pseudoaneurysm $(C, D)$. Coronary angiography showing diffusely diseased left anterior descending artery (E).

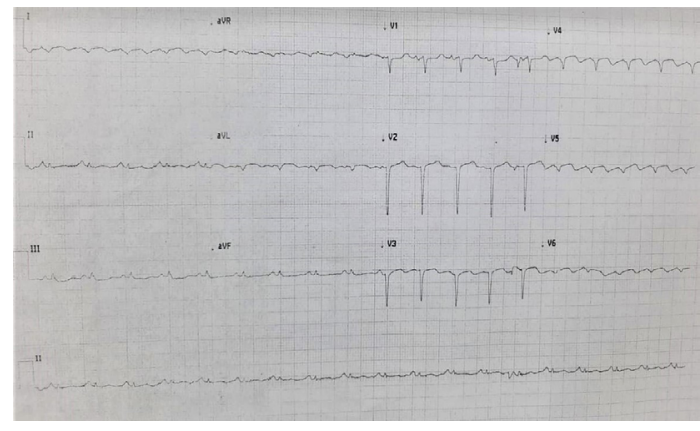

Figure 2 Twelve-lead Electrocardiogram.

descending artery. Anterolateral pseudoaneurysm was confirmed on left ventriculography (video 1) and cardiac MRI (video 2). The patient was offered surgery; however, the relatives and the patient wanted medical management only. At 3 months' follow-up, the patient is alive and can do activities of daily living with minimal dyspnoea.

LV pseudoaneurysm, post MI, has a reported incidence of less than 2\%, with inferior and posterolateral wall being the most common locations $(82 \%$ of all $\mathrm{MI})$, which makes LV anterolateral pseudoaneurysm extremely rare. ${ }^{12}$ It may also occur after cardiac surgery, endovascular interventions and trauma. ${ }^{2}$ The most common presentation is dyspnoea (15\%) followed by chest pain (13\%), arrhythmias/syncope (10\%) and systemic embolism $(6 \%) .{ }^{12}$ While $10 \%$ of the cases may be discovered incidentally, it can also present with cardiac tamponade and sudden cardiac arrest. ${ }^{2}$ Unlike the true aneurysm, it carries a very high risk of

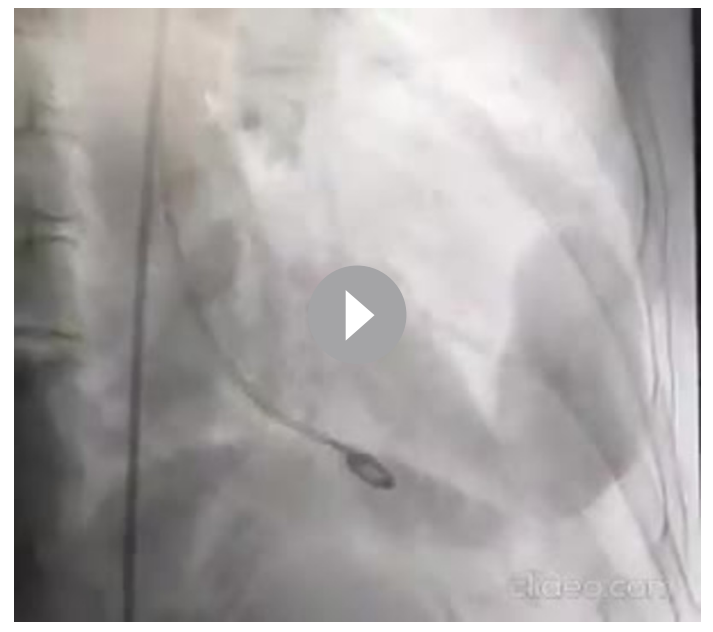

Video 1 Left ventriculogram showing anterolateral pseudoaneurysm. Course of catheter: right femoral artery $\rightarrow$ common iliac artery $\rightarrow$ aorta $\rightarrow$ aortic root $\rightarrow$ left ventricle. 


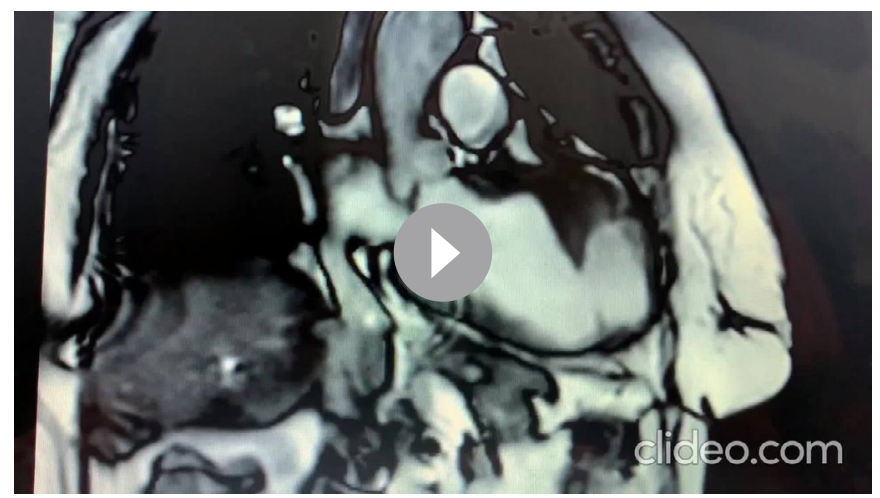

Video 2 Cardiac MRI (vertical long axis) showing left ventricular pseudoaneurysm.

rupture $(30 \%-45 \%) .{ }^{3}$ In majority of the cases, transthoracic echocardiography is sufficient for diagnosis. Besides the typical location, neck diameter ratio of $\leq 0.7$ favours pseudoaneurysm on imaging. ${ }^{34}$ Since our patient had anterolateral pseudoaneurysm which is very rare, we did contrast ventriculography and cardiac MRI to confirm the diagnosis and plan a possible surgical approach. $^{3-5}$ Most symptomatic pseudoaneurysms require

\section{Learning points}

- Left ventricular pseudoaneurysm is a rare, but potentially fatal complication of myocardial infarction, which requires differentiation from true aneurysm.

- Multimodality imaging may sometimes be required to differentiate the pseudoaneurysm from true aneurysm and to plan the surgical management. urgent invasive management; the mortality reaches $50 \%$ on medical therapy, which is halved with surgical intervention. ${ }^{34}$ In patients with high surgical risk, percutaneous closure of LV pseudoaneurysms can be tried, provided it is anatomically feasible. ${ }^{6}$

Our patient had a post MI LV anterolateral pseudoaneurysm which is rare and had a relatively less aggressive course, though long-term follow-up is awaited. In atypical cases, multimodality imaging may be required to confirm the diagnosis.

Twitter Anil Kumar Choudhary @AnilKumaroo7

Contributors NK: Data collection, literature review and writing the origina draft. PP: Planning, conceptualisation, supervision, final review and editing. AKC: Data collection, literature review and writing the original draft. YPS: Planning, conceptualisation, supervision, final review and editing.

Funding The authors have not declared a specific grant for this research from any funding agency in the public, commercial or not-for-profit sectors.

Competing interests None declared.

Patient consent for publication Obtained.

Provenance and peer review Not commissioned; externally peer-reviewed.

\section{ORCID iDs}

Navjyot Kaur http://orcid.org/0000-0002-8392-0798

Prashant Panda http://orcid.org/0000-0002-2420-5209

\section{REFERENCES}

1 Yeo TC, Malouf JF, Oh JK, et al. Clinical profile and outcome in 52 patients with cardiac pseudoaneurysm. Ann Intern Med 1998;128:299-305.

2 Frances C, Romero A, Grady D. Left ventricular pseudoaneurysm. J Am Coll Cardiol 1998;32:557-61.

3 Bisoyi S, Dash AK, Nayak D, et al. Left ventricular pseudoaneurysm versus aneurysm a diagnosis dilemma. Ann Card Anaesth 2016;19:169-72.

4 Brown SL, Gropler RJ, Harris KM. Distinguishing left ventricular aneurysm from pseudoaneurysm. A review of the literature. Chest 1997;111:1403-9.

5 Konen E, Merchant N, Gutierrez C, et al. True versus false left ventricular aneurysm: differentiation with MR imaging--initial experience. Radiology 2005;236:65-75.

6 Cavalcanti LRP, Sá MPBO, Escorel Neto AC, et al. Percutaneous closure of left ventricular pseudoaneurysm in a patient with concomitant true left ventricular aneurysm. J Card Surg 2021;36:2113-6.

Copyright 2021 BMJ Publishing Group. All rights reserved. For permission to reuse any of this content visit

https://www.bmj.com/company/products-services/rights-and-licensing/permissions/

BMJ Case Report Fellows may re-use this article for personal use and teaching without any further permission.

Become a Fellow of BMJ Case Reports today and you can:

- Submit as many cases as you like

- Enjoy fast sympathetic peer review and rapid publication of accepted articles

- Access all the published articles

- Re-use any of the published material for personal use and teaching without further permission

Customer Service

If you have any further queries about your subscription, please contact our customer services team on +44 (0) 2071111105 or via email at support@bmj.com.

Visit casereports.bmj.com for more articles like this and to become a Fellow 